\begin{tabular}{l|l|l|l}
$\begin{array}{c}\text { Case Reports in } \\
\text { Dematology }\end{array}$ & $\begin{array}{l}\text { Case Rep Dermatol 2011;3:80-84 } \\
\text { DOI: } 10.1159 / 000327221\end{array}$ & $\begin{array}{l}\text { Published online: } \\
\text { March 26, 2011 }\end{array}$ & $\begin{array}{l}\text { I 2011 S. Karger AG, Basel } \\
\text { ISSN 1662-6567 } \\
\text { www.karger.com/cde }\end{array}$ \\
\hline
\end{tabular}

\title{
Pyoderma Vegetans Associated with Ulcerative Colitis: A Case with Good Response to Steroids
}

\author{
Filiz Canpolat $^{\mathrm{a}}$ Bengü Çevirgen Cemil ${ }^{\mathrm{a}}$ Demet Yılmazer \\ Okan Yeşillia Fatma Eskioğlu \\ a Department of Dermatology and bepartment of Pathology (2nd), Ministry of \\ Health Diskapi Yildirim Beyazit Education and Research Hospital, Ankara, Turkey
}

\section{Key Words}

Pyodermatitis vegetans $\cdot$ Ulcerative colitis $\cdot$ Steroid

\begin{abstract}
Pyoderma vegetans (PV) is a very rare disorder characterized by erythematous, vesiculopustular, exudative, vegetating plaques usually localized in the inguinal and axillary folds. The etiology of PV is not known, but it is often associated with bacterial infections in immunocompromised patients. Major histopathological features in PV are pseudoepitheliomatous hyperplasia and intraepidermal and subepidermal neutrophilic or eosinophilic microabscesses. It is well known that these lesions are frequently associated with inflammatory bowel diseases, such as ulcerative colitis (UC) and Crohn's disease. No standardized treatment plan is available for PV, although antibiotic treatment has often been used, with variable results. The standard first-line therapy is still systemic steroids. Herein, we report a case of PV associated with UC with unusual localization that showed a good response to systemic corticosteroid, antibiotic and sulfasalazine therapy.
\end{abstract}

\section{Introduction}

Pyoderma vegetans (PV), is a very rare, chronic inflammatory dermatosis. It is characterized by large exudative, verrucous plaques with well-defined and elevated borders [1]. PV often affects middle-aged men, is frequently associated with ulcerative colitis (UC) and is often difficult to treat [2]. Other diseases that might be linked to this condition include cutaneous T-cell lymphoma, primary immunodeficiencies, chronic myeloid leukemia, alcoholism, HIV infection and nutritional deficit [2-4]. Predisposing factors include microbial infections, halogen ingestion, foreign materials and tattoos in patients with a compromised immune system [3]. However, it has also been reported in healthy patients $[2,5]$. Major histopathological features in PV are pseudoepitheliomatous 


\begin{tabular}{l|l|l|l}
$\begin{array}{c}\text { Case Reports in } \\
\text { Demmatoloyy }\end{array}$ & $\begin{array}{l}\text { Case Rep Dermatol 2011;3:80-84 } \\
\text { DOI: } 10.1159 / 000327221\end{array}$ & $\begin{array}{l}\text { Published online: } \\
\text { March 26, 2011 }\end{array}$ & $\begin{array}{l}\text { O 2011 S. Karger AG, Basel } \\
\text { ISSN 1662-6567 } \\
\text { www.karger.com/cde }\end{array}$ \\
\hline
\end{tabular}

hyperplasia and intraepidermal and subepidermal neutrophilic or eosinophilic microabscesses [6].

Here, we present a case report of PV associated with UC and a short review of the literature on the therapeutic challenge of this rare disorder.

\section{Case Report}

A 64-year-old man presented to our clinic with a 1-month history of well-defined, vegetating plaques with elevated borders on the fingers of the left hand and on the toes and the medial malleolus of the left foot (igg. 1, fig. 2). He had been diagnosed with UC 20 years previously and had been treated with sulfasalazine at that time.

According to the clinical symptoms, uncontrolled, subtotal colectomy was made for UC, which resulted in stabilization of the disease without sulfasalazine. However, he had a history of intermittent bloody diarrhea and mucus for the following 2 months.

Laboratory tests revealed a white blood cell count of $12.4 \times 10^{9}$ per liter (normal: $4-10 \times 10^{9}$ ), a red blood cell count of 3.91 million/ $\mu \mathrm{l}$ (normal: $4.2-5.4$ ), hemoglobin $10.6 \mathrm{~g} / \mathrm{dl}$ (normal: $12-16$ ), hematocrit $34.1 \%$ (normal: $37-47$ ) and a sedimentation rate of $46 \mathrm{~mm} / \mathrm{h}$ (normal: $0-20$ ). Wound culture was positive for Staphylococcus aureus. Fungal culture was negative. Histopathological examination revealed marked pseudoepitheliomatous hyperplasia with a dense inflammatory infiltrate composed of neutrophils in the upper dermis (fig. 3, fig. 4). Direct immunofluorescence tests were negative. Based on these findings, the diagnosis of PV was established. The patient was treated with fluocortolone 60 $\mathrm{mg}$ /day, amoxicillin clavulanate $1 \mathrm{~g}$ twice daily and topical wound care with aluminium subacetate dressing. Treatment for the relapse of UC was started with sulfasalazine and metronidazole. The skin lesions cleared from postinflammatory hyperpigmentation within weeks parallel to the relief of colitis. Corticosteroids were gradually tapered and stopped over 8 weeks and the patient was continued on sulfasalazine.

\section{Discussion}

$\mathrm{PV}$, also named blastomycosis-like pyoderma, is a very rare disease. It is referred to as 'pyostomatitis vegetans' when mucosal lesions are observed. It was believed that PV was the result of a bacterial invasion in immunosuppressive patients [1]. Because the skin lesions usually occur on the trunk and the groin, the remarkably well-defined, vegetating plaques with elevated borders on fingers and toes in our case seemed to be an unusual clinical presentation. The diagnosis of the disease depends on five criteria which were proposed by Su et al. [7]: large verrucous plaques with multiple pustules and elevated border, pseudoepitheliomatous hyperplasia with abscesses in tissue biopsy, growth of at least one pathogenic bacterium, negative culture for deep fungi, atypical mycobacteria or mycobacterium tuberculosis and normal bromide levels. The main pitfall is the risk of clinically misdiagnosing this rare condition. Since pemphigus vegetans may show clinical and histopathological findings similar to PV, the two are difficult to distinguish from each other $[4,6]$. The differential diagnosis of PV should include pemphigus vegetans and deep fungal infections. Tuberculosis cutis verrucosa, pyoderma gangrenosum, halogenoderma, squamous cell carcinoma and Sweet syndrome must also be ruled out [1-3]. To differentiate PV from other diseases, evaluations of wound, yeast and mycobacterium tuberculosis culture and direct immunofluorescence study must be performed in order to rule out pemphigus vegetans. The association of PV with UC is well known but rarely reported in literature $[2,3,6,8-10]$. Since PV is considered a marker of inflammatory 


\begin{tabular}{l|l|l|l}
$\begin{array}{c}\text { Case Reports in } \\
\text { Demmatoloyy }\end{array}$ & $\begin{array}{l}\text { Case Rep Dermatol 2011;3:80-84 } \\
\text { DOI: } 10.1159 / 000327221\end{array}$ & $\begin{array}{l}\text { Published online: } \\
\text { March 26, 2011 }\end{array}$ & $\begin{array}{l}\text { O 2011 S. Karger AG, Basel } \\
\text { ISSN 1662-6567 } \\
\text { www.karger.com/cde }\end{array}$ \\
\hline
\end{tabular}

bowel disease, a presumptive diagnosis of PV should induce a complete gastrointestinal investigation.

Although numerous treatments have been tried for PV, the condition is usually very difficult to treat effectively. The treatment of PV focuses on control of the underlying disease. In previously reported cases, the skin lesions regressed after management of bowel disease with sulfasalazine, mesalazine or colectomy $[3,8]$. Despite the bacterial etiology of the lesions in PV, systemic antibiotics alone are no effective treatment $[7,11]$. Topical application of disodium cromoglycate has been used in the treatment of PV which was refractory to antibiotic therapy [12]. The standard first-line therapy is systemic steroids at a dose of 0.5 to $1.0 \mathrm{mg} / \mathrm{kg}$. The response to systemic steroids is usually very good $[11,13]$. Many other treatment modalities, including dapsone, azathioprine, cyclosporine and laser debridement, have been reported only anecdotally in case reports and are generally accepted as second-line therapies $[1,2,10,13]$. Besides these therapies, topical tacrolimus complementing total colectomy has also been reported to be beneficial in cleaning lesions [10]. Carrera et al. [1] also reported a patient with PV and psoriasis who was successfully treated with etanercept. Our patient was treated with sulfasalazine for UC and with steroid and antibiotic for the cutaneous lesions.

PV has a good prognosis with therapy. Its evolution tends to follow the progression of the underlying intestinal disorder [11]. It is important to be familiar with this vegetative skin condition, as correct diagnosis may lead to the uncovering of inflammatory bowel disease. The management of PV includes several agents, but definite guidelines are still lacking.

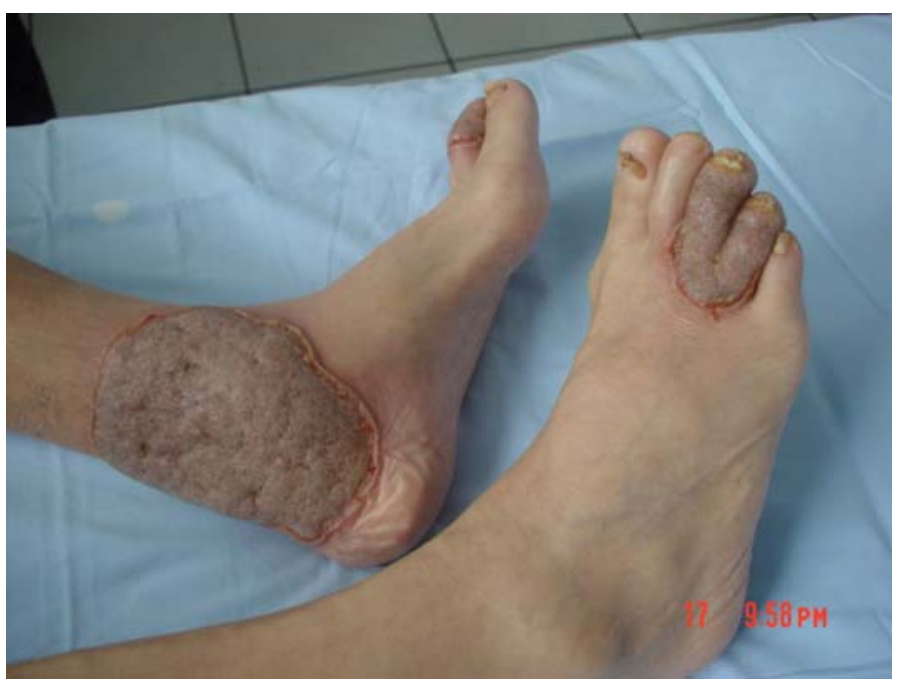

Fig. 1. Circumscribed vegetating plaques with erythematous elevated borders on the toes and medial malleolus of the left foot. 


\begin{tabular}{l|l|l|l}
$\begin{array}{c}\text { Case Reports in } \\
\text { Demmatoloyy }\end{array}$ & $\begin{array}{l}\text { Case Rep Dermatol 2011;3:80-84 } \\
\text { DOI: } 10.1159 / 000327221\end{array}$ & $\begin{array}{l}\text { Published online: } \\
\text { March 26, 2011 }\end{array}$ & $\begin{array}{l}\text { O 2011 S. Karger AG, Basel } \\
\text { ISSN 1662-6567 } \\
\text { www.karger.com/cde }\end{array}$ \\
\hline
\end{tabular}

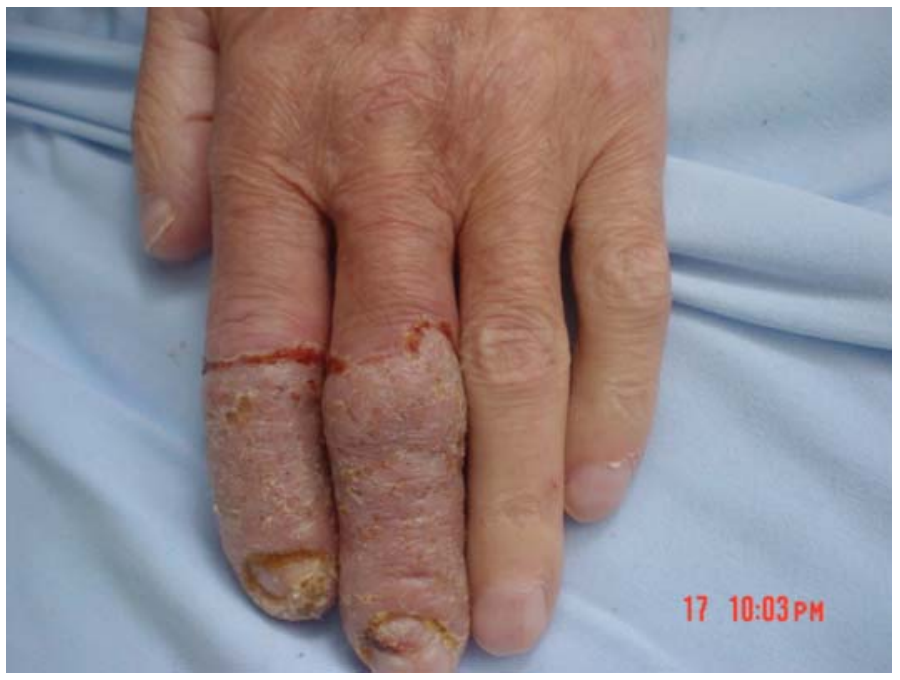

Fig. 2. Well-defined erythematous, crusted and vegetating plaques on the fingers.

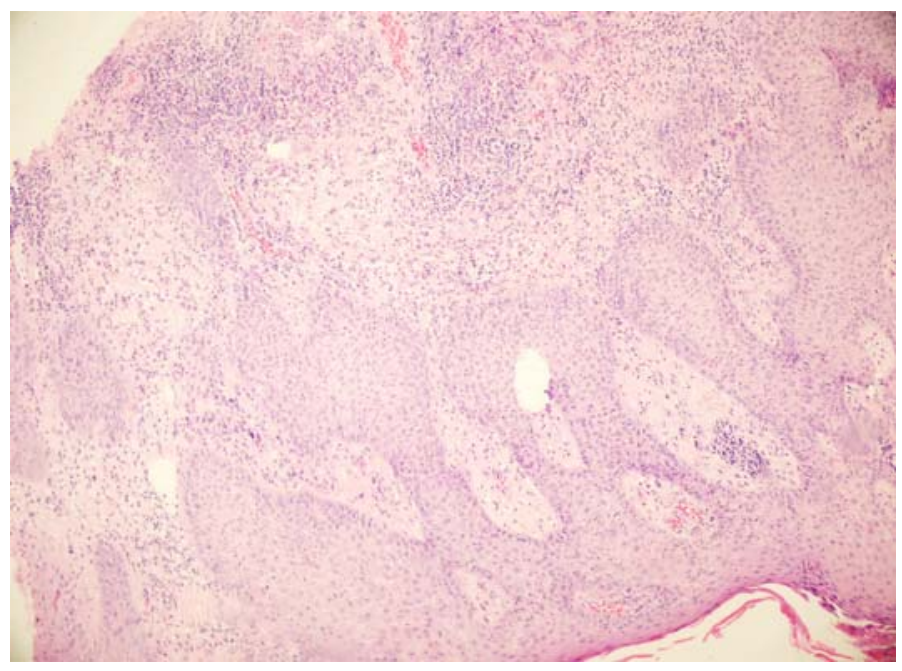

Fig. 3. Pseudoepitheliomatous hyperplasia with a dense inflammatory infiltrate composed of neutrophils was observed in the upper dermis (hematoxylin-eosin staining, $\times 40$ ). 


\begin{tabular}{l|l|l|l}
$\begin{array}{l}\text { Case Reports in } \\
\text { Dematology }\end{array}$ & $\begin{array}{l}\text { Case Rep Dermatol 2011;3:80-84 } \\
\text { DOI: 10.1159/000327221 }\end{array}$ & $\begin{array}{l}\text { Published online: } \\
\text { March 26, 2011 }\end{array}$ & $\begin{array}{l}\text { O 2011 S. Karger AG, Basel } \\
\text { ISSN 1662-6567 } \\
\text { www.karger.com/cde }\end{array}$ \\
\hline
\end{tabular}

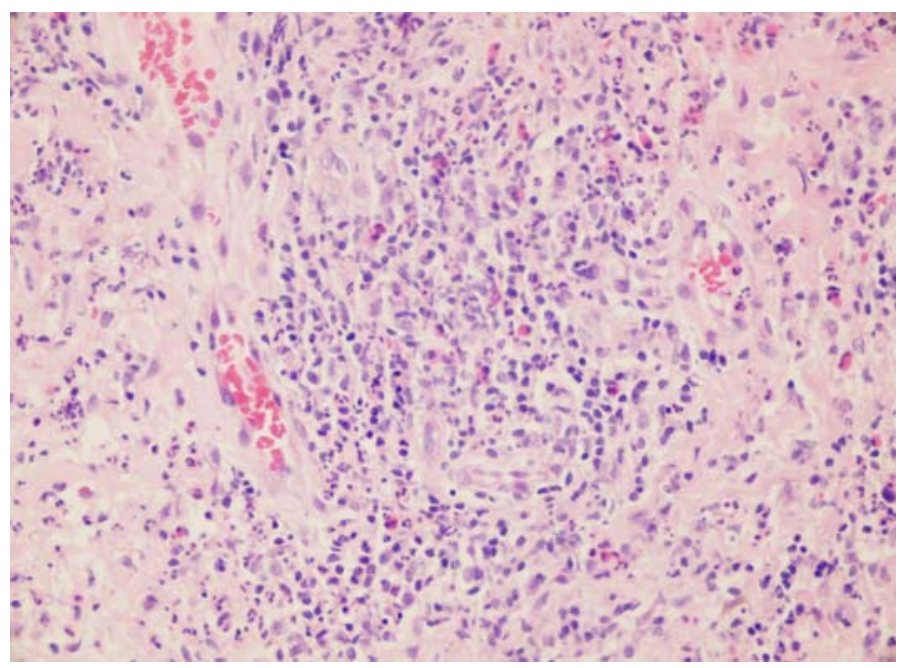

Fig. 4. Eosinophils and neutrophils aggregate to form abscesses in the dermis (hematoxylin-eosin staining, $\times 100)$.

\section{References}

1 Carrera C, Mascaró JM Jr, Moreno-Romero JA, et al: Pyoderma vegetans associated with severe psoriatic arthritis: good response to etanercept. Dermatology 2007;214:77-81.

-2 Adişen E, Tezel F, Gürer MA: Pyoderma vegetans: a case for discussion. Acta Derm Venereol 2009;89:186-188.

3 Bianchi L, Carrozzo AM, Orlandi A, Campione E, Hagman JH, Chimenti S: Pyoderma vegetans and ulcerative colitis. Br J Dermatol 2001;144:1224-1227.

4 Papadopoulos AJ, Schwartz RA, Kapila R, et al: Pyoderma vegetans. J Cutan Med Surg 2001;5:223-227.

5 Brinkmeier T, Frosch PJ: Pyodermatitis-pyostomatitis vegetans: a clinical course of two decades with response to cyclosporine and low-dose prednisolone. Acta Derm Venereol 2001;81:134-136.

-6 Soriano ML, Martínez N, Grilli R, Fariña MC, Martín L, Requena L: Pyodermatitis-pyostomatitis vegetans: report of a case and review of the literature. Oral Surg Oral Med Oral Pathol Oral Radiol Endod 1999;87:322326.

7 Su WPD, Duncan S, Perry HO: Blastomycosis-like pyoderma. Arch Dermatol 1979;115:170-173.

8 Kitayama A, Misago N, Okawa T, Iwakiri R, Narisawa Y: Pyodermatitis-pyostomatitis vegetans after subtotal colectomy for ulcerative colitis. J Dermatol 2010;37:714-717.

\$9 Harish K, Varghese T, Najeeba R, Harikumar R: Pyoderma vegetans and ulcerative colitis. J Postgrad Med 2006;52:302-303.

10 Yasuda M, Amano H, Nagai Y, Tamura A, Ishikawa O, Yamaguchi S: Pyodermatitis-pyostomatitis vegetans associated with ulcerative colitis: successful treatment with total colectomy and topical tacrolimus. Dermatology 2008;217:146-148.

-11 Nigen S, Poulin Y, Rochette L, Lévesque MH, Gagné E: Pyodermatitis-pyostomatitis vegetans: two cases and a review of the literature. J Cutan Med Surg 2003;7:250-255.

12 Rongioletti F, Semino M, Drago F, Blangetti MG, Rebora A: Blastomycosis-like pyoderma (Pyoderma vegetans) responding to antibiotics and topical disodium chromoglycate. Int J Dermatol 1996;35:828-830.

13 Leibovitch I, Ooi C, Huilgol SC, Reid C, James CL, Selva D: Pyodermatitis-pyostomatitis vegetans of the eyelids case report and review of the literature. Ophthalmology 2005;112:1809-1813. 